\title{
A SCORING SYSTEM TO PREDICT THE RISK OF SURGICAL SITE INFECTIONS AFTER SPINAL SURGERY
}

\author{
SISTEMA DE PONTUAÇÃO PARA PREVER O RISCO DE INFECÇÕES LOCAIS DEPOIS DE \\ CIRURGIA DA COLUNA
}

\section{SISTEMA DE PUNTUACIÓN PARA PREDECIR EL RIESGO DE INFECCIONES LOCALES DESPUÉS DE CIRUGÍA DE LA COLUMNA}

\author{
Ivan Andreevich Stepanov ${ }^{1,2}$, Vladimir Anatol'evich Beloborodov", Mariya Anatol'evna Shameeva', Eduard Borisovich Borisov ${ }^{3}$ \\ 1. Irkutsk State Medical University, Department of General Surgery and Anesthesiology, Irkutsk, Russia. \\ 2. Kharlampiev Clinic, Department of Neurology and Neurosurgery, Irkutsk, Russia. \\ 3. Buryat Republican Clinical Oncology Center, Department of Head and Neck Tumors, Ulan-Ude, Russia.
}

\begin{abstract}
Objective: This retrospective clinical study was carried out to generate and cross-validate a scoring system for the identification of patients at risk of SSIs after spinal surgery. Methods: A retrospective study was conducted, which included patients who underwent spinal surgery. The potential variables for SSIs were extracted from the database, including preoperative, intraoperative and postoperative risk factors for univariate and multivariate regression analyses. Results: A total of 2347 patients were included in this retrospective clinical study. Postoperative SSIs were observed in 53 patients (2.2\%). The multivariate logistic regression analysis revealed the following risk factors for SSIs after spinal surgery: diabetes mellitus $(P=0.029)$, body mass index $(P=0.008)$, low serum calcium concentration $(P=0.012)$, low pre- and postoperative albumin $(P=0.023, P=0.037)$, more than three operated segments $(P=0.008)$, operation time of more than 180 minutes $(P=0.019)$, estimated blood loss $(P=0.011)$, low postoperative hemoglobin $(P=0.017)$ and prolonged drainage time $(P=0.025)$. Each of these factors contributed 1 point to the risk score. The predicted rates of incidence for the low-, intermediate-, high-, and extremely high-risk categories in the validation set were $1.4 \%, 12 \%, 41.6 \%$, and $66.6 \%$, respectively. Conclusions: Our scoring system allows for easy and validated risk stratification of SSIs after spinal surgery. Level of evidence III; Cross-sectional Observational Study.
\end{abstract}

Keywords: Surgical Wound Infection; Spine; Risk Factors; Risk Assessment.

\section{RESUMO}

Objetivo: Este estudo clínico cruzado retrospectivo foi realizado para gerar e validar um sistema de pontuação para a identificação de pacientes com risco de ICL após cirurgia da coluna vertebral. Métodos: Foi realizado um estudo retrospectivo que incluiu pacientes submetidos à cirurgia de coluna vertebral. As possíveis variáveis para ICL foram extraídas do banco de dados, incluindo fatores de risco pré-operatórios, intraoperatórios e pós-operatórios para análises de regressão univariada e multivariada. Resultados: Um total de 2.347 pacientes foram incluídos neste estudo clínico retrospectivo. As ICLs pós-operatórias foram observadas em 53 pacientes (2,2\%). A análise de regressão logística multivariada revelou os seguintes fatores de risco de ICL depois de cirurgia da coluna: diabetes mellitus $(P=0,029)$, índice de massa corporal $(P=0,008)$, baixa concentração sérica de cálcio $(P=0,012)$, albumina pré e pós-operatória baixa $(P=0,023, P=0,037)$, mais de três segmentos operados $(P=0,008)$, tempo de cirurgia superior a 180 minutos $(P=0,019)$, perda de sangue estimada $(P=0,011)$, hemoglobina pós-operatória baixa $(P=0,017)$ e tempo prolongado de drenagem $(P=0,025)$. Cada um desses fatores contribuiu com 1 ponto para o escore de risco. As taxas de incidência previstas para as categorias de risco baixo, intermediário, alto e extremamente alto no conjunto de validação foram 1,4\%, 12\%, 41,6\% e 66,6\%, respectivamente. Conclusões: Nosso sistema de pontuação permite uma estratificação de risco fácil e validada das ICLs depois de cirurgia da coluna. Nível de evidência III; Estudo Observacional Transversal.

Descritores: Infecção da Ferida Cirúrgica; Coluna Vertebral; Fatores de Risco; Medição de risco.

\section{RESUMEN}

Objetivo: Este estudio clínico cruzado retrospectivo se realizó para generar y validar un sistema de puntuación para la identificar pacientes en riesgo de IQL después de cirugía de columna. Métodos: Se realizó un estudio retrospectivo que incluyó pacientes sometidos a cirugía de columna. Las posibles variables de IQL se recopilaron de la base de datos, incluidos los factores de riesgo preoperatorios, intraoperatorios y posoperatorios para análisis de regresión univariados y multivariados. Resultados: Se incluyó un total de 2.347 pacientes. Las IQLs posoperatorias se observaron en 53 pacientes (2,2\%). El análisis de regresión logística multivariante reveló los siguientes factores de riesgo de IQL después de cirugía de columna: diabetes mellitus $(P=0,029)$, índice de masa corporal $(P=0,008)$, baja concentración sérica de calcio $(P=0,012)$, albúmina baja en el período pre y posoperatorio $(P=0,023, P=0,037)$, más de tres segmentos operados

Study conducted at the Irkutsk State Medical University, Irkutsk, Russia.

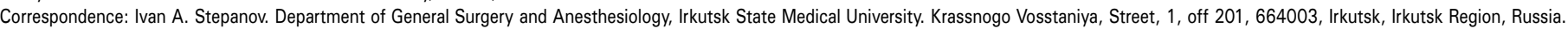
stepanovivanneuro@gmail.com 
$(P=0,008)$, tiempo de cirugía mayor de 180 minutos $(P=0,019)$, pérdida de sangre estimada $(P=0,011)$, hemoglobina postoperatoria baja $(P=0,017)$ y tiempo de drenaje prolongado $(P=0,025)$. Cada uno de estos factores contribuyó con 1 punto a la puntuación de riesgo. Las tasas de incidencia previstas para las categorías de riesgo bajo, intermedio, alto y extremadamente alto en el conjunto de validación fueron 1,4\%, 12\%, 41,6\% y 66,6\%, respectivamente. Conclusiones: Nuestro sistema de puntuación permite una estratificación de riesgo fácil y validada de las IQLS después de la cirugía de columna. Nivel de evidencia III; Estudio observacional transversal.

Descriptores: Infección de la Herida Quirúrgica; Columna Vertebral; Factores de Riesgo; Medición de Riesgo.

\section{INTRODUCTION}

Surgical site infections (SSIs) are among the most common nosocomial infections, accounting for 14 to $16 \%$ of nosocomial infections overall and $38 \%$ of nosocomial infections among surgical patients. ${ }^{1,2}$ SSIs can lead to prolonged hospitalization, increased morbidity and mortality, increased surgery-related costs, and decreased quality of life. ${ }^{3}$ According to data from the National Nosocomial Infections Surveillance System (NNIS), approximately 1.2\% of patients who underwent laminectomy and $12.4 \%$ of those who underwent the surgical procedure of spinal fusion developed SSIs. ${ }^{4}$ The rate of SSIs in the literature ranges from $0.2 \%$ to $12.0 \%$, depending on the type of surgical procedure, the diagnosis, and the use of instrumentation. ${ }^{5,6}$

It is well known that the variability in infection risk is related to the nature of the procedure, with more complicated spinal surgical procedures having higher infection rates. ${ }^{7}$ Besides surgery-related factors, certain patient characteristics are also associated with increased risk for SSIs. ${ }^{8}$ It is difficult to predict, before surgery, which patients are at risk of developing SSIs. Knowing about the risk factors for SSI after spinal surgical procedures can help policy-makers to plan preventive strategies to reduce the incidence of SSI.

The NNIS risk index was developed in the early 1990s and has been used to predict the risk of SSI across a broad range of surgical procedures. ${ }^{9}$ The NNIS risk index score, which ranges from 0 to 3 , reflects how many of the following risk factors are present: American Society of Anesthesiologists (ASA) preoperative score of III or higher, an operation classified as contaminated or dirty, and an operation lasting for over three hours. ${ }^{10}$ The NNIS risk index is a general score, and has been criticized for being overly simplistic as it does not consider specific aspects of spinal surgery. One component of the NNIS risk index - duration of the surgical procedure - cannot be determined prior to surgery, so the score cannot be used for preoperative preventive measures.

It is necessary to identify more procedure-specific risk factors for use in risk adjustment and in the application of preventive measures for individual patients. The aim of this retrospective clinical study was to generate and cross-validate a scoring system for the identification of patients at risk of SSI after spinal surgery.

\section{METHODS}

\section{Study design and participants}

This clinical study was approved by the ethics committee (Protocol \# 53/4) of Irkutsk State Medical University (Irkutsk, Russia) and informed consent was obtained from all the patients before their participation. This was a retrospective study that included patients who had undergone spinal surgery between June 2011 and March 2020. The inclusion criteria were: (1) a diagnosis of cervical or thoracic lumbar spinal degenerative disease, such as spinal stenosis, disc herniation and spondylolisthesis, and vertebral fracture; (2) different surgical approaches; (3) elective, non-emergency surgical procedures. Cases of spinal infections, tumor, tuberculosis, or spinal deformity, combined with multiple fractures of the extremities and open spinal injury were excluded from this clinical study.

\section{Variables and definitions}

SSIs include superficial and deep infection. The definition of SSI comes from the guidelines published by the U.S. Centers for Disease
Control and Prevention. In this study, SSI was specified as acute spinal infection within 30 days after lumbar spinal surgery. Patients who met one of the following criteria were diagnosed as having an SSI: (1) a wound presenting symptoms or signs of redness, swelling, fever, pain, tenderness on palpation and/or purulent drainage; (2) a positive abscess drainage culture; (3) a positive culture for fluid or tissue harvested from revision surgery; (4) confirmation by histopathologic and radiologic examinations; (5) SSI diagnosed by the surgeons and recorded in the medical records.

The potential variables for SSIs were extracted from the database. These include (1) preoperative factors (sex, age, body mass index, hypertension, diabetes mellitus, white blood cells, red blood cells, thrombocyte, total protein, hemoglobin, albumin, globulin, serum calcium, serum potassium, glycated serum protein), (2) intraoperative factors (number of operated segments, ASA (American Society of Anesthesiologists) classification, duration of operation, estimated blood loss, surgical procedure, allogenic blood transfusion) and (3) postoperative risk factors (white blood cells, red blood cells, thrombocyte, total protein, hemoglobin, albumin, globulin, serum calcium, serum potassium, glycated serum protein, drainage time) for univariate and multivariate regression analyses.

\section{Statistical analysis}

The continuous data were reported as the mean $\pm S D$ and the differences between groups were analyzed using t tests. The categorical data are presented as a proportion percentage and were analyzed using the $\chi^{2}$ test or Fisher's exact test. The covariates with $P<0.05$ in the univariate analysis were subsequently included in a multivariate binary logistic regression model. The variables that remained significant in the multivariate analysis were used to construct a scoring system to classify the patients into groups, according to their risk of SSI. The Hosmer-Lemeshow test was used to check the goodness-of-fit of the model and the predictive value of the multivariate model was expressed using the $c$-statistic. Statistical significance was defined as $P<0.05$. Statistical analysis was performed using SPSS 22.0 (IBM Corp. Armonk, NY) and Microsoft Office Excel 2016 (Microsoft Corp., Redmond, Washington).

\section{RESULTS}

A total of 2347 patients were included in this retrospective clinical study, following the inclusion and exclusion criteria. Of these, 998 (42.5\%) were diagnosed with intervertebral disk herniation, 674 (28.7\%) with different types of spinal spondylolisthesis, 427 (18.19\%) with spinal stenosis and 248 (10.5\%) with vertebral fracture. Postoperative SSIs were observed in 53 patients (2.2\%) (46 - superficial SSIs and 7 - deep incisional SSIs): 38 males and 15 females, with an average age of $56.5 \pm 11.3$ years.

Of these, the surgical procedures were as follows: 23 (43.3\%) lumbar interbody fusion, $12(22.6 \%)$ open transforaminal lumbar interbody fusion (O-TLIF), 3 (5.6\%) minimally invasive transforaminal lumbar interbody fusion (MI-TLIF), 5 (9.5\%) direct (lateral) lumbar interbody fusion (D(L)LIF), 3 (5.6\%) anterior lumbar interbody fusion (ALIF), 9 (11.3\%) thoracic spine fusion, and 21 (39.6\%) posterior cervical fusion. A further 110 patients who had undergone spinal surgery during the same period, without any postoperative adverse events, were included in this retrospective clinical study for comparative analysis. 


\section{Preoperative risk factors for SSIs}

Table 1 shows the preoperative characteristics of patients with and without SSIs. The univariate analysis revealed the following preoperative adverse risk factors for SSIs: diabetes mellitus $(P=0.031)$, body mass index $(P=0.016)$, low total protein $(P=0.042)$, low hemoglobin $(P=0.012)$, low albumin $(P=0.004)$ and decreased serum calcium concentration $(P=0.007)$.

\section{Intraoperative risk factors for SSIs}

Table 2 shows the results of the univariate analysis of intraoperative risk factors for SSI. The factor analysis included number of operated segments, ASA classification, duration of operation, estimated blood loss, surgical procedure and allogenic blood transfusion. There were statistically significance differences in the number of operated segments $(P=0.003)$, ASA classification $(P=0.044)$, duration of operation $(P=0.027)$ and type of surgical procedure $(P=0.035)$.

\section{Postoperative risk factors for SSIs}

Table 3 shows the postoperative characteristics of patients in the two groups. The univariate analysis revealed the following

Table 1. Univariate analysis of preoperative risk factors for SSIs after spinal surgery.

\begin{tabular}{c|c|c|c}
\hline Risk factors & $\begin{array}{c}\text { SSI group } \\
(\mathbf{n}=\mathbf{5 3})\end{array}$ & $\begin{array}{c}\text { Non-SSI } \\
\text { group } \\
(\mathbf{n = 1 1 0 )}\end{array}$ & $\mathbf{P}$ \\
\hline Sex, $\mathbf{n}(\mathbf{\%})$ & & & $\mathbf{0 . 9 9 2}$ \\
\hline Male & $38(71.6)$ & $82(74.5)$ & \\
\hline Female & $15(28.3)$ & $18(16.3)$ & \\
\hline Age, (years) & $56.5 \pm 11.3$ & $56.2 \pm 10.8$ & 0.853 \\
\hline Body mass index, $\left(\mathrm{kg} / \mathrm{m}^{2}\right)$ & $28,5 \pm 5.7$ & $22.6 \pm 4.1$ & 0.016 \\
\hline Arterial hypertension, $\mathrm{n}(\%)$ & $19(35.8)$ & $47(42.7)$ & 0.614 \\
\hline Diabetes mellitus, $\mathrm{n}(\%)$ & $12(22.6)$ & $21(19)$ & 0.031 \\
\hline White blood cells, $\left(\times 10^{9} / \mathrm{l}\right)$ & $7.1 \pm 3.7$ & $6.9 \pm 2.5$ & 0.319 \\
\hline Red blood cells, $\left(\times 10^{12} / \mathrm{l}\right)$ & $4.2 \pm 0.7$ & $4.4 \pm 0.5$ & 0.128 \\
\hline Thrombocyte, $\left(\times 10^{9} / \mathrm{l}\right)$ & $215.7 \pm 69.9$ & $213.4 \pm 67.7$ & 0.937 \\
\hline Total protein, $(\mathrm{g} / \mathrm{l})$ & $65.7 \pm 6.4$ & $67.5 \pm 5.8$ & 0.042 \\
\hline Hemoglobin, $(\mathrm{g} / \mathrm{l})$ & $122.6 \pm 17.5$ & $131.9 \pm 16.5$ & 0.012 \\
\hline Albumin, $(\mathrm{g} / \mathrm{l})$ & $38.8 \pm 3.8$ & $41.4 \pm 3.7$ & 0.004 \\
\hline Globulin, $(\mathrm{g} / \mathrm{l})$ & $25.7 \pm 5.3$ & $26.1 \pm 4.8$ & 0.447 \\
\hline Serum calcium, $(\mathrm{mmol} / \mathrm{l})$ & $2.27 \pm 0.16$ & $2.39 \pm 0.11$ & 0.007 \\
\hline Serum potassium, $(\mathrm{mmol} / \mathrm{l})$ & $3.89 \pm 0.49$ & $4.01 \pm 0.38$ & 0.088 \\
\hline Serum glucose, $(\mathrm{mmol} / \mathrm{l})$ & $5.88 \pm 2.37$ & $5.48 \pm 2.41$ & 0.154 \\
\hline Glycated serum protein, $(\mathrm{mmol} / \mathrm{l})$ & $2.08 \pm 0.39$ & $2.13 \pm 0.26$ & 0.215 \\
\hline & & &
\end{tabular}

Table 2. Univariate analysis of intraoperative risk factors for SSls after spinal surgery.

\begin{tabular}{c|c|c|c}
\hline Risk factors & $\begin{array}{c}\text { SSI group } \\
(\mathbf{n = 5 3 )}\end{array}$ & $\begin{array}{c}\text { Non-SSI group } \\
(\mathbf{n = 1 1 0 )}\end{array}$ & $\mathbf{P}$ \\
\hline Number of operated segments, $\mathrm{n}$ & $2.1 \pm 1.1$ & $1.4 \pm 0.7$ & 0.003 \\
\hline ASA classification & $2.4 \pm 0.5$ & $2.3 \pm 0.5$ & 0.044 \\
\hline Duration of operation, (minutes) & $156.8 \pm 62.5$ & $131.5 \pm 47.7$ & 0.027 \\
\hline Estimated blood loss, (ml) & $619.8 \pm 359.9$ & $571.3 \pm 221.5$ & 0.118 \\
\hline $\begin{array}{c}\text { Type of surgical spinal } \\
\text { procedure, } \mathrm{n}(\%)\end{array}$ & & & 0.035 \\
\hline O-TLIF & $12(22.6)$ & $26(23.6)$ & \\
\hline Ml-TLIF & $3(5.6)$ & $37(33.6)$ & \\
\hline D(L)LIF & $5(9.5)$ & $10(9.1)$ & \\
\hline ALIF & $3(5.6)$ & $5(4.5)$ & \\
\hline Thoracic spine fusion surgery & $9(11.3)$ & $13(11.8)$ & \\
\hline Posterior cervical spine fusion & $21(39.6)$ & $19(17.3)$ & \\
\hline surgery & & & 0.627 \\
\hline Allogenic blood fusion, $\mathrm{n}(\%)$ & $14(26.4)$ & $22(20)$ & \\
\hline+ & $39(73.5)$ & $88(80)$ & \\
\hline- & & &
\end{tabular}

postoperative risk factors for SSIs: serum concentrations of thrombocyte $(P=0.017)$, hemoglobin $(P=0.009)$, albumin $(P=0.001)$, calcium $(P=0.006)$ and drainage time $(P=0.001)$.

\section{Multivariate logistic regression analysis}

All related pre- intra- and postoperative risk factors resulting from the univariate analyses were included in the logistic regression model (Table 4). The multivariate logistic regression analysis revealed the following risk factors for SSI after spinal surgery: diabetes mellitus $(P=0.029)$, body mass index $(P=0.008)$, low serum concentration of calcium $(P=0.012)$, low pre- and postoperative albumin $(P=0.023, P=0.037)$, more than three operated segments $(P=0.008)$, operation lasting more than 180 minutes $(P=0.019)$, estimated blood loss $(P=0.011)$, low postoperative hemoglobin $(P=0.017)$ and prolonged drainage time $(P=0.025)$. The Hosmer-Lemeshow test confirmed a good overall model fit $\left(\chi^{2}=5.447\right.$, $P=0.634)$. The model was highly discriminatory in our study population, with a c-statistic of $0.637(P<0.001)$.

\section{A scoring system for SSIs after spinal surgery}

Despite the differences in the logistic regression coefficients, which ranged from 0.719 to 1.376 for SSIs after spinal surgery procedures, respectively, for the sake of simplicity, one point was assigned for each of the risk factors. The resulting scores were built for SSIs after spinal surgery. Because only seven of the patients had ten points, the following four risk groups were established: low risk (0 points), intermediate risk (1-4 points), high risk (5-8 points), and extremely high risk (more than 8 points). In this retrospective study, the distribution of the patients according to the scoring system for SSIs was as follows: low risk - 35 (66.1\%), intermediate risk - 12 (22.6\%), high risk - 5 (9.4\%), and extremely high risk - $1(1.8 \%)$ $(P=0.004)$ (Table 5).

Table 3. Univariate analysis of postoperative risk factors for SSIs after spinal surgery.

\begin{tabular}{c|c|c|c}
\hline Risk factors & $\begin{array}{c}\text { SSI group } \\
(\mathbf{n}=\mathbf{5 3})\end{array}$ & $\begin{array}{c}\text { Non-SSI group } \\
(\mathbf{n}=\mathbf{1 1 0})\end{array}$ & $\mathbf{P}$ \\
\hline White blood cells, $\left(\times 10^{9} / \mathrm{l}\right)$ & $11.1 \pm 3.5$ & $12.2 \pm 3.1$ & 0.077 \\
\hline Red blood cells, $\left(\times 10^{12} / \mathrm{l}\right)$ & $3.3 \pm 0.5$ & $3.4 \pm 0.4$ & 0.135 \\
\hline Thrombocyte, $\left(\times 10^{9} / \mathrm{l}\right)$ & $221.7 \pm 93.3$ & $189.7 \pm 68.5$ & 0.017 \\
\hline Total protein, $(\mathrm{g} / \mathrm{l})$ & $54.6 \pm 8.1$ & $54.5 \pm 7.9$ & 0.691 \\
\hline Hemoglobin, $(\mathrm{g} / \mathrm{l})$ & $95.2 \pm 21.1$ & $107.3 \pm 17.7$ & 0.009 \\
\hline Albumin, $(\mathrm{g} / \mathrm{l})$ & $38.8 \pm 3.8$ & $41.4 \pm 3.7$ & 0.004 \\
\hline Globulin, $(\mathrm{g} / \mathrm{l})$ & $21.9 \pm 5.6$ & $22.3 \pm 4.8$ & 0.121 \\
\hline Serum calcium, $(\mathrm{mmo} / \mathrm{l})$ & $2.09 \pm 0.17$ & $2.18 \pm 0.13$ & 0.006 \\
\hline Serum potassium, $(\mathrm{mmol} / \mathrm{l})$ & $3.88 \pm 0.51$ & $3.96 \pm 0.37$ & 0.205 \\
\hline Serum glucose, $(\mathrm{mmol} / \mathrm{l})$ & $6.51 \pm 1.92$ & $6.45 \pm 1.74$ & 0.088 \\
\hline Glycated serum protein, $(\mathrm{mmol} / \mathrm{l})$ & $1.67 \pm 0.25$ & $1.74 \pm 0.31$ & 0.114 \\
\hline Drainage time $(\mathrm{days})$ & $2.89 \pm 1.03$ & $2.36 \pm 0.92$ & 0.001 \\
\hline
\end{tabular}

Table 4. Multivariate logistic regression analysis of risk factors for SSIs after spinal surgery.

\begin{tabular}{c|c|c|c}
\hline Risk factors & $\begin{array}{c}\text { Odds ratio } \\
\text { [95\% Confidence } \\
\text { interval] }\end{array}$ & $\begin{array}{c}\text { Regression } \\
\text { coefficient }\end{array}$ & $\mathbf{P}$ \\
\hline Body mass index & $1.19[1.04-1.77]$ & 0.905 & 0.008 \\
\hline Diabetes mellitus & $2.18[1.07-4.61]$ & 0.719 & 0.029 \\
\hline Preoperative serum calcium & $0.01[0.001-0.39]$ & 0.884 & 0.012 \\
\hline Preoperative serum glucose & $1.12[1.01-1.35]$ & 1.225 & 0.072 \\
\hline Preoperative albumin & $0.76[0.55-0.99]$ & 1.105 & 0.023 \\
\hline Number of operated segments & $2.27[1.47-3.51]$ & 1.376 & 0.008 \\
\hline Duration of operation & $1.29[1.02-1.84]$ & 1.145 & 0.019 \\
\hline Estimated blood loss & $1.09[1.01-1.07]$ & 0.914 & 0.011 \\
\hline Postoperative hemoglobin & $0.87[0.77-1.01]$ & 0.931 & 0.017 \\
\hline Postoperative albumin & $0.68[0.35-0.97]$ & 0.768 & 0.037 \\
\hline Drainage time (days) & $1.39[1.04-2.08]$ & 0.856 & 0.025 \\
\hline
\end{tabular}




\section{Discrimination}

The final models discriminated the development sets with the areas under the receiver operating characteristic (ROC) curve. The area under the ROC curve was $0.727(0.654-0.793)$ for the multivariate logistic regression model and $0.724(0.655-0.787)$ for the simplified score for SSIs after spinal surgery (Figure 1). To evaluate the performance of the models, the observed versus predicted incidence rates in the validation set were compared. The predicted incidence rates for the low-, intermediate-, high-, and extremely high-risk categories in the validation set were 1.4\%, 12\%, $41.6 \%$, and $66.6 \%$, respectively. There were no statistically significant differences between the observed and predicted incidence rates for SSIs in the validation set $(P>0.05)$.

Table 5. A scoring system to predict the risk of surgical site infections after spinal surgery.

\begin{tabular}{c|c|c|c|c|c}
\hline Risk groups & $\begin{array}{c}\text { Risk } \\
\text { scores }\end{array}$ & $\mathrm{n}(\%)$ & $\mathrm{n}(\%)$ & $\begin{array}{c}\text { Odds ratio } \\
\text { [95\% Confidence } \\
\text { interval]I }\end{array}$ & $\mathrm{P}$ \\
\hline Low & 0 & $67(60.9)$ & $1(1.4)$ & $1[-]$ & - \\
\hline Intermediate & $1-4$ & $25(22.7)$ & $3(12)$ & $2.11[1.48-3.89]$ & 0.034 \\
\hline High & $5-8$ & $12(10.9)$ & $5(41.6)$ & $5.67[2.53-10.93]$ & 0.004 \\
\hline Extremely high & $>8$ & $6(5.4)$ & $1(66.6)$ & $\begin{array}{c}33.74[15.31- \\
69.87]\end{array}$ & 0.002 \\
\hline
\end{tabular}

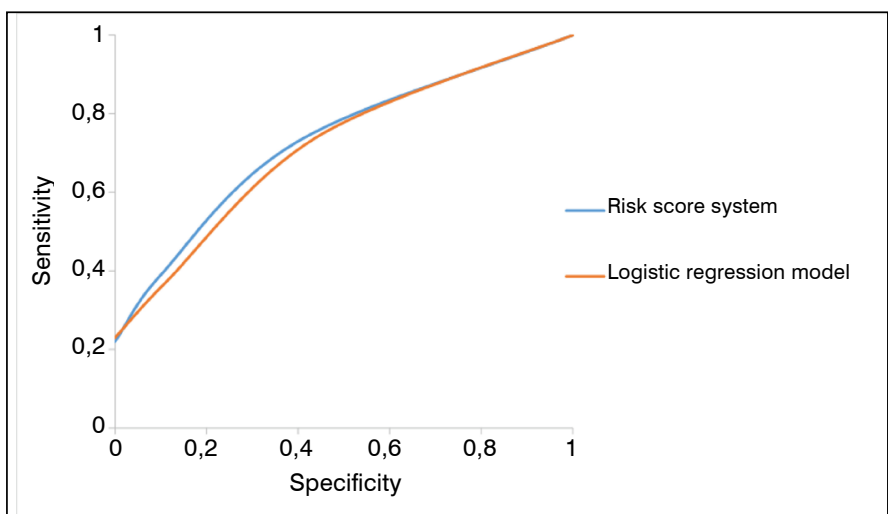

Figure 1. ROC curves for prediction of SSIs after spinal surgery in the development sets.

\section{DISCUSSION}

As already noted, SSls after spinal surgery lead to increased morbidity, secondary surgical procedures, hospital readmissions, poorer clinical and radiological outcomes, and increased costs. ${ }^{11-13}$ Many previous clinical studies have reported the prevalence and risk factors of SSIs after spinal surgery. Liu et al., ${ }^{14}$ conducted a large-scale single-institution retrospective study including 2715 patients who underwent lumbar fusion surgery, and demonstrated that the prevalence of SSIs was $2.4 \%$. The authors of that study also reported that diabetes mellitus, preoperative serum calcium, serum glucose, albumin, number of fused segments, surgical duration, estimated blood loss, postoperative hemoglobin, albumin and drainage time were significant risk factors for SSIs. A systematic review and meta-analysis by Fei et al., ${ }^{15}$ included 12 studies. They reported that diabetes mellitus, prolonged operative times ( $>3$ hours), body mass index $\left(>35 \mathrm{~kg} / \mathrm{m}^{2}\right)$, posterior approach, and the number of intervertebral levels $(\geq 7)$ are associated with an increased risk of SSIs after spinal surgery. According to a meta-analysis Peng et al., ${ }^{16}$ which included 26 observational studies, diabetes mellitus, body mass index $\left(>30 \mathrm{~kg} / \mathrm{m}^{2}\right)$, arterial hypertension, $\geq 3$ hours operative time and transfusion were closely associated with a remarkable increase in the risk of SSIs after spinal surgery procedures. Following previous clinical studies, the prevalence of SSIs after spinal surgery in our study, based on our study population of 2347 patients, was $2.2 \%$. Our result concerning the risk factors of SSIs is consistent with those of previous studies.

Few articles have been designed to create a scoring system for predicting the risk of SSIs after different surgical procedures. Gervaz et al., ${ }^{17}$ illustrated a simple clinical score based on four preoperative variables (obesity, contamination class, ASA classification and open surgery), which was clinically useful in predicting the risk of SSIs in patients undergoing colorectal surgery. In a similar article Alavi et al., ${ }^{18}$ reported a simple risk score for predicting SSIs in inflammatory bowel disease. The authors of that clinical study showed that preoperative factors, including weight loss, smoking, emergent surgery and ASA classification $>2$, are strong predictors of SSIs. Moreover, operative time and wound class are important intraoperative predictors. Among these systems, the NNIS basic risk index is one of the most widely used to predict the risk of SSIs. ${ }^{19}$ The NNIS basic SSI risk index consists of the following three criteria: ASA classification, wound class; and duration of operation. Unfortunately, the NNIS basic SSIs risk index might be not suitable for spine surgery.

To the best of our knowledge, no studies have been designed to develop a scoring system to predict the risk of SSIs after spinal surgical procedures. Our scoring system was based on the logistic regression model. For the risk stratification for SSIs, a scoring system classified the patients after spinal surgery into four groups - low, intermediate, high and extremely high. A scoring system to predict the risk of SSIs after spinal surgery discriminated the development sets with an area under the ROC curve of 0.724 , which is similar to the logistic regression model. The scoring system did not show any statistically significant differences between the observed and predicted incidence rates in the validation set, indicating that the system performed well. Patient and disease parameters data are routinely available, which might have implications for selecting risk-adapted procedures to improve surgical safety. Since only the body mass index can be identified in the preoperative period, patients with obesity $\left(>25 \mathrm{~kg} / \mathrm{m}^{2}\right)$ might be referred to surgeons with more experience, in order to reduce operation times and intraoperative blood loss. Also, if one or more of their other risk factors occurs intraoperatively or postoperatively, it is necessary to pay close attention to the signs and symptoms, conducting laboratory tests and radiological examinations in the postoperative period to ensure early detection and treatment of SSIs.

\section{Limitations}

This study has some limitations. First, as with other retrospective studies, inherent selective bias is inevitable, although we used a prospectively collected database. Second, data were acquired from hospitals and centers located in Russia, which use varying degrees of equipment and may not be generalizable. Broader representation would enhance the generalizability of the results to nonparticipating hospitals and surgeons.

\section{CONCLUSIONS}

Our scoring system allows for easy and validated risk stratification of SSIs after spinal surgery. This stratification might help in the selection of risk-adapted procedures to reduce the rates of SSI and improve surgical safety. A multicenter randomized controlled trial study with a large series would help validate this scoring system.

All authors declare no potential conflict of interest related to this article.

CONTRIBUTION OF THE AUTHORS: Each author made significant individual contributions to this manuscript. IAS: writing, data collection and analysis, intellectual concept, preparation of the whole research project and review; VAB: data collection and analysis; MAS: statistical analysis and review; EBB: review and intellectual concept. 


\section{REFERENCES}

1. Anderson PA, Savage JW, Vaccaro AR, Radcliff K, Arnold PM, Lawrence BD, et al. Prevention of Surgical Site Infection in Spine Surgery. Neurosurgery. 2017;80(3S):S114-23. doi: 10.1093/neuros/nyw066.

2. Mangram AJ, Horan TC, Pearson ML, Silver LC, Jarvis WR. Guideline for prevention of surgical site infection, 1999. Hospital Infection Control Practices Advisory Committee. Infect Control Hosp Epidemiol. 1999;20(4):250-80. doi: 10.1086/501620.

3. Smith RL, Bohl JK, McElearney ST, Friel CM, Barclay MM, Sawyer RG, et al. Wound infection after elective colorectal resection. Ann Surg. 2004:239(5):599-607.

4. Horan TC, Gaynes RP, Martone WJ, Jarvis WR, Emori TG. CDC definitions of nosocomial surgical site infections, 1992: a modification of CDC definitions of surgical wound infections. Am J Infect Control. 1992;13(10):606-8.

5. Mehta Al, Babu R, Sharma R, Karikari IO, Grunch BH, Owens TR, et al. Thickness of subcutaneous fat as a risk factor for infection in cervical spine fusion surgery. J Bone Joint Surg Am. 2013;95(4):323-8. doi: 10.2106/JBJS.L.00225.

6. Picada R, Winter RB, Lonstein JE, Denis F, Pinto MR, Smith MD, et al. Postoperative deep wound infection in adults after posterior lumbosacral spine fusion with instrumentation: incidence and management. J Spinal Disord. 2000;13(1):42-5. doi: 10.1097/00002517200002000-00009.

7. Fang $A$, Hu SS, Endres N, Bradford DS. Risk factors for infection after spinal surgery. Spine (Phila Pa 1976). 2005;30(12):1460-5. doi: 10.1097/01.brs.0000166532.58227.4f.

8. Massie JB, Heller JG, Abitbol JJ, McPherson D, Garfin SR. Postoperative posterior spinal wound infections. Clin Orthop Relat Res. 1992;(284):99-108.

9. Culver DH, Horan TC, Gaynes RP, Martone WJ, Jarvis WR, Emori TG, et al. Surgical wound infection rates by wound class, operative procedure, and patient risk index. National Nosocomial Infections Surveillance System. Am J Med. 1991;91(3B):152S-7S. doi: 10.1016/0002-9343(91)90361-z.

10. Vandenbroucke-Grauls $C$, Schultsz C. Surveillance in infection control: are we making progress?. Curr Opin Infect Dis. 2002;15(4):415-9.

11. Butler JS, Wagner SC, Morrissey PB, Kaye ID, Sebastian AS, Schroeder, et al. Strate- gies for the Prevention and Treatment of Surgical Site Infection in the Lumbar Spine. Clin Spine Surg. 2018;31(8):323-30. doi: 10.1097/BSD.0000000000000635.

12. Haimoto S, Schär RT, Nishimura Y, Hara M, Wakabayashi T, Ginsberg HJ. Reduction in surgical site infection with suprafascial intrawound application of vancomycin powder in instrumented posterior spinal fusion: a retrospective case-control study. J Neurosurg Spine. 2018:29(2):193-198. doi: 10.3171/2017.12.SPINE17997.

13. Ogihara S, Yamazaki T, Maruyama T, Oka H, Miyoshi K, Azuma S, et al. Prospective multicenter surveillance and risk factor analysis of deep surgical site infection after posterior thoracic and/or lumbar spinal surgery in adults. J Orthop Sci. 2015;20(1):71-7. doi: 10.1007/ s00776-014-0669-1.

14. Vandenbroucke-Grauls $C$, Schultsz $C$. Surveillance in infection control: are we making progress?. Curr Opin Infect Dis. 2002;15(4):415-9.

15. Fei Q, Li J, Lin J, Li D, Wang BQ, Meng H, et al. Risk Factors for Surgical Site Infection After Spinal Surgery: A Meta-Analysis. World Neurosurg. 2016;95:507-15. doi: 10.1016/j. wneu.2015.05.059.

16. Peng XQ, Sun CG, Fei ZG, Zhou QJ. Risk Factors for Surgical Site Infection After Spinal Surgery: A Systematic Review and Meta-Analysis Based on Twenty-Seven Studies. World Neurosurg. 2019;123:e318-29. doi: 10.1016/j. wneu.2018.11.158.

17. Gervaz P, Bandiera-Clerc C, Buchs NC, Eisenring MC, Troillet N, Perneger T, et al. Scoring system to predict the risk of surgical-site infection after colorectal resection. Br J Surg 2012:99(4):589-595. doi: 10.1002/bjs.8656.

18. Alavi K, Sturrock PR, Sweeney WB, Maykel JA, Cervera-Servin JA, Tseng J, et al. A simple risk score for predicting surgical site infections in inflammatory bowel disease. Dis Colon Rectum. 2010;53(11):1480-6.

19. Culver DH, Horan TC, Gaynes RP, Martone WJ, Jarvis WR, Emori TG, et al. Surgical wound infection rates by wound class, operative procedure, and patient risk index. National Nosocomial Infections Surveillance System. Am J Med. 1991;91(3B):152S-7S. doi: 10.1016/0002-9343(91)90361-z. 